\title{
ACET is a highly potent and specific kainate receptor antagonist: Characterisation and effects on hippocampal mossy fibre function
}

\author{
Sheila L. Dargan ${ }^{\mathrm{a}, *, 1}$, Vernon R.J. Clarke ${ }^{\mathrm{a}, 1}$, Gregory M. Alushin ${ }^{\mathrm{b}}$, John L. Sherwood ${ }^{\mathrm{a}}$, Robert Nisticò ${ }^{\mathrm{a}}$, \\ Zuner A. Bortolotto a , Ann M. Ogden ${ }^{c}$, David Bleakman ${ }^{c}$, Andrew J. Doherty ${ }^{a}$, David Lodge ${ }^{a}$, \\ Mark L. Mayer $^{b}$, Stephen M. Fitzjohn ${ }^{a}$, David E. Jane ${ }^{a}$, Graham L. Collingridge ${ }^{a}$ \\ ${ }^{a}$ MRC Centre for Synaptic Plasticity, University of Bristol, Bristol BS8 1TD, UK \\ ${ }^{\mathrm{b}}$ Laboratory of Cellular and Molecular Neurophysiology, Porter Neuroscience Research Center, NICHD, NIH, DHHS, Bethesda, MD 20892, USA \\ ${ }^{\mathrm{c}}$ Neuroscience Research, Eli Lilly and Company, Lilly Corporate Center, Indianapolis, IN 46285, USA
}

\section{A R T I C L E I N F O}

Article history:

Received 3 June 2008

Received in revised form 4 August 2008

Accepted 7 August 2008

\section{Keywords:}

Hippocampus

Mossy fibre LTP

Calcium

Kainate

ACET

GluR5

GluK1

X-ray crystallography

2-Photon

\begin{abstract}
A B S T R A C T
Kainate receptors (KARs) are involved in both NMDA receptor-independent long-term potentiation (LTP) and synaptic facilitation at mossy fibre synapses in the CA3 region of the hippocampus. However, the identity of the KAR subtypes involved remains controversial. Here we used a highly potent and selective GluK1 (formerly GluR5) antagonist (ACET) to elucidate roles of GluK1-containing KARs in these synaptic processes. We confirmed that ACET is an extremely potent GluK1 antagonist, with a $K_{\mathrm{b}}$ value of $1.4 \pm 0.2 \mathrm{nM}$. In contrast, ACET was ineffective at GluK2 (formerly GluR6) receptors at all concentrations tested (up to $100 \mu \mathrm{M}$ ) and had no effect at GluK3 (formerly GluR7) when tested at $1 \mu \mathrm{M}$. The X-ray crystal structure of ACET bound to the ligand binding core of GluK1 was similar to the UBP310-GluK1 complex. In the CA1 region of hippocampal slices, ACET was effective at blocking the depression of both fEPSPs and monosynaptically evoked GABAergic transmission induced by ATPA, a GluK1 selective agonist. In the CA3 region of the hippocampus, ACET blocked the induction of NMDA receptor-independent mossy fibre LTP. To directly investigate the role of pre-synaptic GluK1-containing KARs we combined patch-clamp electrophysiology and 2-photon microscopy to image $\mathrm{Ca}^{2+}$ dynamics in individual giant mossy fibre boutons. ACET consistently reduced short-term facilitation of pre-synaptic calcium transients induced by 5 action potentials evoked at $20-25 \mathrm{~Hz}$. Taken together our data provide further evidence for a physiological role of GluK1-containing KARs in synaptic facilitation and LTP induction at mossy fibre-CA3 synapses.
\end{abstract}

(c) 2008 Elsevier Ltd. All rights reserved.

\section{Introduction}

Kainate receptors (KARs) are widely expressed in the central nervous system, where they mediate excitatory neurotransmission, modulate neurotransmitter release and contribute to the induction of synaptic plasticity (Lerma, 2003; Pinheiro and Mulle, 2008; Jane et al., 2009). KARs are heteromeric assemblies of four subunits, comprised of various combinations of the five different subunits GluK1-5, which are derived from the genes GRIK 1-5 respectively (Collingridge et al., 2009). In addition to playing important roles in normal brain function, such as hippocampal network activity (Fisahn, 2005; Huxter et al., 2007) and recognition memory (Barker et al., 2006), KARs have also been implicated in pathophysiological conditions such as epilepsy (Vincent and Mulle, in press), chronic

\footnotetext{
* Corresponding author. Tel.: +44 117331 1967; fax: +44 1179291687.

E-mail address: sheila.dargan@bristol.ac.uk (S.L. Dargan).

${ }^{1}$ These authors contributed equally to this work.
}

pain (Blackburn-Munro et al., 2004; Bleakman et al., 2006) and manic behaviour in bipolar disorder (Shaltiel et al., 2008).

The development and functional characterisation of novel potent and selective compounds is essential for understanding the contribution of KAR subtypes in neuronal processes, and for the identification of new drug targets. The prototypic GluK1 selective antagonists, such as LY382884 (O'Neill et al., 1998) have low micromolar potency. We therefore developed a series of KAR antagonists based on the structure of the AMPA receptor agonist willardiine (More et al., 2002, 2003). Over the past few years, a combination of structure-activity relationship studies and homology models (More et al., 2004; Dolman et al., 2005, 2006) have been used to create novel compounds that show a marked selectivity for GluK1 with potencies ranging from micromolar (UBP296, UBP302 and UBP304) to nanomolar (UBP310). More recently, X-ray crystal structures of the GluK1-specific antagonists UBP302 and UBP310 bound to the ligand binding core (Mayer et al., 2006) have been used to design additional GluK1 antagonists that are more 
potent and selective and potentially have greater bioavailability (Dolman et al., 2007). The most potent in this series is UBP316 ((S)-1-(2-amino-2-carboxyethyl)-3-(2-carboxy-5-phenylthiophene3-yl-methyl)-5-methylpyrimidine-2,4-dione), a compound that we have named ACET.

Initial electrophysiological experiments using the GluK1 selective antagonist LY382884 identified essential roles for GluK1containing KARs in NMDA receptor-independent mossy fibre LTP (Bortolotto et al., 1999) and synaptic facilitation (Lauri et al., 2001a,b, 2003). However, an independent report using LY382884 failed to detect a role for GluK1 in these synaptic processes (Breustedt and Schmitz, 2004). This controversy is further compounded by experimental findings from studies using KAR subunit knockout mice (Mulle et al., 1998; Contractor et al., 2001; Schmitz et al., 2003; Breustedt and Schmitz, 2004), which argue against a role for GluK1 in synaptic facilitation and LTP, suggesting instead a role for GluK2 or GluK2/GluK3 heteromers (Pinheiro et al., 2007).

In the present study we have extended our pharmacological characterisation of ACET and have obtained an X-ray crystal structure of ACET bound to the ligand binding core of GluK1. We have also used ACET to re-investigate the physiological roles of KARs in NMDAR-independent mossy fibre LTP and to study the pre-synaptic regulation of $\mathrm{Ca}^{2+}$ facilitation in giant mossy fibre boutons. Our findings substantiate a role for GluK1-containing KARs in both of these synaptic processes.

\section{Methods}

\subsection{Pharmacological compounds}

ACET was synthesised in house by methods stated previously (Dolman et al. 2007) and made up in equimolar sodium hydroxide to pH 7. GYKI 53655 and LY382884 (Bleisch et al., 1997) were synthesised at Eli Lilly and Company and were prepared in DMSO. All other drugs were purchased from commercial suppliers and made up following company suggestions: D-AP5, ATPA, CGP 55845 and L-689,560 were purchased from Tocris Bioscience (Bristol, UK); glutamate and NBQX were purchased from Ascent (Weston-Super-Mare, UK); concanavalin A was purchased from Sigma (Poole, UK); fluorescent probes and lipofectamine 200 were purchased from Invitrogen (San Diego, CA, USA).

\subsection{Calcium fluorescence assays using kainate receptor subtypes}

HEK293 cells stably expressing human GluK1 or GluK2 (Bleakman et al., 1996) were maintained as monolayers in Dulbecco's modified Eagle's medium (DMEM) supplemented with $2 \mathrm{mM}$ glutamine and $10 \%$ foetal bovine serum. Passage numbers less than 15 were used. Cells were seeded into black-walled 96 well plates (Costar 3603, Corning Inc., Life Sciences) coated with poly-D-lysine 1-2 days prior to experimentation at approximately 30,000-60,000 cells/well. When cells just reached confluence, they were washed twice with $100 \mu$ l of HBS buffer (in mM) $\mathrm{NaCl}(150), \mathrm{KCl}(3)$, HEPES (10), D-glucose (10), $\mathrm{CaCl}_{2}$ (2), pH 7.4. Cells were incubated for at least $1 \mathrm{~h}$ with $50 \mu \mathrm{l}$ of buffer plus $10 \mu \mathrm{M}$ Fluo3-AM, rinsed twice with modified HBS containing $5 \mathrm{mM} \mathrm{CaCl}_{2}$ without D-glucose (referred to as 'assay buffer') and then incubated with $162 \mu \mathrm{l}$ of assay buffer plus $250 \mu \mathrm{g} \mathrm{ml}^{-1}$ concanavalin A for at leas $30 \mathrm{~min}$ prior to being transferred to a fluorometric plate reader (Flexstation 2; Molecular Devices, Sunnyvale, CA, USA). A range of concentrations of the test compound were prepared in assay buffer containing concanavalin A. During the first run, the plate reader added $18 \mu \mathrm{l}$ of antagonist, buffer (control wells for subsequent L-glutamate application), or L-glutamate (to obtain a dose-response curve to L-glutamate). During the second run, $20 \mu \mathrm{l}$ of L-glutamate plus antagonist was added to give a final L-glutamate concentration of either $10 \mu \mathrm{M}$ (GluK2) or $30 \mu \mathrm{M}$ (GluK1) Antagonism was calculated as $100(X-Y) / X$ where $X$ and $Y$ are the maximum fluorescence in the absence and presence of a fixed dose of antagonist. For each plate, an $\mathrm{EC}_{50}$ for L-glutamate and $\mathrm{IC}_{50}$ for antagonist were obtained from dose-response curves fitted with the Hill equation with slope coefficient fixed to 1 . The within-plate $\mathrm{EC}_{50}$ for L-glutamate and $\mathrm{IC}_{50}$ for antagonist were then used to calculate the dissociation constant $\left(K_{\mathrm{b}}\right)$ using the Cheng-Prusoff equation; $K_{\mathrm{b}}=\mathrm{IC}_{50} /\left(1+[A] / \mathrm{EC}_{50}\right)$ where $[A]$ is the concentration of agonist used to determine $I_{50}$ values of antagonist.

\subsection{Electrophysiology on HEK cells expressing human-recombinant GluK3}

HEK293 cells were maintained in DMEM/F12 (3:1)/5\% FBS/20 mM HEPES. 200,000 cells were plated into a $35 \mathrm{~mm}$ plate containing $412 \mathrm{~mm}$ poly-t-lysine round coverslips (BD Biocoat) and allowed to adhere overnight in a $37{ }^{\circ} \mathrm{C} 5 \mathrm{CO}_{2}$ incubator. The next day coverslips were transiently transfected drop wise using $2 \mu \mathrm{g}$ $\mathrm{ml}$ human GluK3(Q) and $2 \mu \mathrm{g} / \mathrm{ml}$ vYFP in pcDNA3.1 plus in $250 \mu \mathrm{l}$ lipofectamine 200 ,
$20 \mu \mathrm{g} / \mathrm{ml}$ solution. Cells were preincubated in concanavalin $\mathrm{A}(500 \mu \mathrm{g} / \mathrm{ml})$ for $10 \mathrm{~min}$. Electrophysiology was performed the next day as described previously (More et al., 2004), except cells were held at $-80 \mathrm{mV}$.

\subsection{Crystallography}

The GluK1 S1S2 ligand binding core was over-expressed and purified as previously described (Mayer, 2005). Protein was exhaustively dialyzed against a glutamate-free crystallization buffer containing (in mM) ACET (0.01-0.03), $\mathrm{NaCl}(40)$ HEPES (20) and EDTA (2) before dilution at a 1:1 volume ratio with $3.3 \mathrm{mM}$ ACET dissolved in equimolar $\mathrm{NaOH}$. The resulting solution was mixed at a 1:1 volume ratio with a reservoir solution containing 18-20\% PEG $1 \mathrm{~K}$ and $100 \mathrm{mM}$ TRIS $\mathrm{Cl}$ pH 8.7-8.9 and hanging drops setup at $20^{\circ} \mathrm{C}$. The GluK1 S1S2 concentration was $5-10 \mathrm{mg} / \mathrm{ml}$. Within 1-2 days the drops were micro-seeded, initially with crystals of the UBP310 complex. Crystals were harvested in a cryo solution containing $18 \%$ glycerol. Data from a single crystal were collected using synchrotron radiation at APS (Table 1). The ACET complex structure was solved by difference Fourier methods, using the UBP310 complex (PDB 2F34) stripped of ligand, solvent, and alternative conformations as a starting model. The model was rebuilt with COOT (Emsley and Cowtan, 2004) followed by cycles of restrained refinement with REFMAC5 (Winn et al., 2001), with 3-4 TLS groups per subunit identified by TLSMD (Painter and Merritt, 2006); there was no electron density for the first three residues and last four residues in the C-terminus. Figures were prepared using PYMOL (DeLano, 2002). Coordinates and structure factors for the ACET complex have been deposited with the PDB code 2QS3.

Table 1

Data collection and refinement statistics

\begin{tabular}{|c|c|}
\hline \multicolumn{2}{|l|}{ Data collection } \\
\hline Space group & $\mathrm{C} 222_{1}$ \\
\hline \multicolumn{2}{|l|}{ Unit cell dimensions $(\AA)$} \\
\hline$a b c$ & 97.897 .7128 .6 \\
\hline Number per a.u. & 2 \\
\hline Wavelength $(\AA)$ & 1.0000 \\
\hline Resolution $(\AA)^{\mathrm{a}}$ & $40-1.76(1.82)$ \\
\hline Unique observations & 61,223 \\
\hline Mean redundancy ${ }^{\mathrm{b}}$ & $5.3(5.3)$ \\
\hline Completeness $(\%)^{\mathrm{b}}$ & $98.2(98.6)$ \\
\hline$R_{\text {merge }} \mathrm{b}, \mathrm{c}$ & $0.037(0.381)$ \\
\hline$I / \sigma(I)^{\mathrm{b}}$ & $13.8(4.00)$ \\
\hline Mosaicity & 0.17 \\
\hline \multicolumn{2}{|l|}{ Refinement } \\
\hline Resolution $(\AA)$ & $32-1.76$ \\
\hline Protein atoms (alt conf) & $4014(244)$ \\
\hline ACET atoms & 60 \\
\hline PEG atoms & 32 \\
\hline $\mathrm{Cl}$ ions & 2 \\
\hline Water atoms & 409 \\
\hline$R_{\text {work }} / R_{\text {free }}(\%)^{\mathrm{d}}$ & $18.8 / 21.8$ \\
\hline \multicolumn{2}{|l|}{ rms deviations } \\
\hline Bond lengths $(\AA)$ & 0.008 \\
\hline Bond angles (degrees) & 1.19 \\
\hline Bonds B values $\mathrm{Mc} / \mathrm{Sc}^{\mathrm{e}}$ & $0.515 / 1.219$ \\
\hline Angles $\mathrm{B}$ values $\mathrm{Mc} / \mathrm{Sc}^{\mathrm{e}}$ & $0.872 / 1.896$ \\
\hline \multicolumn{2}{|l|}{ Mean $B$ values $\left(\AA^{2}\right)$} \\
\hline Protein overall & 29.97 \\
\hline Main-chain/side-chain & $29.6 / 30.33$ \\
\hline ACET & 34.34 \\
\hline PEG & 21.86 \\
\hline $\mathrm{Cl}$ & 21.89 \\
\hline Water & 39.13 \\
\hline Ramachandran $\%{ }^{\mathrm{f}}$ & $93.2 / 0$ \\
\hline
\end{tabular}

${ }^{a}$ Values in parenthesis indicate the low resolution limit for the highest-resolution shell of data.

b Values in parenthesis indicate statistics for the highest-resolution shell of data

${ }^{c} R_{\text {merge }}=\left(\sum\left|I_{I}-\left\langle I_{I}\right\rangle\right|\right) / \sum I\left|I_{I}\right|$, where $\left\langle I_{I}\right\rangle$ is the mean $I_{I}$ over symmetry-equivalent reflections.

${ }^{\mathrm{d}} R_{\text {work }}=\left(\sum|| F_{0}|-| F_{\mathrm{c}} \mid\right) / \sum\left|F_{\mathrm{o}}\right|$, where $F_{\mathrm{o}}$ and $F_{\mathrm{c}}$ denote observed and calculated structure factors, respectively; $5 \%$ of the reflections were set aside for the calculation of the $R_{\text {free }}$ value.

Main-chain/side-chain.

${ }^{\mathrm{f}}$ Preferred/disallowed conformations. 


\subsection{Preparation of hippocampal brain slices}

All animal experiments were carried out in accordance with the UK Scientific Procedures Act, 1986 and associated guidelines. Efforts were made to minimise suffering, reduce the number of animals used and utilise alternatives where available. Animals were housed in a regulated environment $\left(21 \pm 1^{\circ} \mathrm{C}\right)$ with a $12 \mathrm{~h} \mathrm{light}$ dark cycle, and food was available ad libitum. Animals were killed by cervical dislocation.

For in vitro extracellular and intracellular recordings, $400 \mu \mathrm{m}$ parasagittal slices were prepared from female Wistar rats (110-160 g) purchased from Harlan or P14 rats bred in house. Tissue was cut in ice-cold artificial cerebrospinal fluid (ACSF) comprising (in mM) NaCl (124), D-glucose (10), $\mathrm{NaHCO}_{3}$ (26), $\mathrm{KCl}$ (3), $\mathrm{NaH}_{2} \mathrm{PO}_{4}$ (1.25), $\mathrm{CaCl}_{2}$ (2) and $\mathrm{MgSO}_{4}$ (1) saturated with $95 \% \mathrm{O}_{2}$ and $5 \% \mathrm{CO}_{2}$. For recordings in the CA1, the CA3 area was removed. After a recovery period of at least 40 min slices were transferred to an interface recording chamber, maintained at $29-31{ }^{\circ} \mathrm{C}$ and perfused with ACSF at a rate of $1.8-2.2 \mathrm{ml} / \mathrm{min}$.

For the 2-photon calcium imaging experiments (Figs. 6 and 7) slightly thicker slices $(500 \mu \mathrm{m})$ were prepared from male P14 rats using a method that involves isolating the hippocampi and cutting "transverse" slices at a slight angle $\left(\sim 20^{\circ}\right)$ to optimise the presence of intact mossy fibres (Scott and Rusakov, 2006). Cutting solution comprised (in mM): $\mathrm{NaCl}(124), \mathrm{KCl}(3), \mathrm{NaHCO}_{3}$ (26), $\mathrm{NaH}_{2} \mathrm{PO}_{4}$ (1.4), $\mathrm{CaCl}_{2}$ (1), $\mathrm{MgSO}_{4}(10)$, D-glucose (10) saturated with $95 \% \mathrm{O}_{2}$ and $5 \% \mathrm{CO}_{2}$. Slices were warmed to $34{ }^{\circ} \mathrm{C}$ for $40 \mathrm{~min}$ to aid recovery, then maintained for more than $1 \mathrm{~h}$ at room temperature prior to recording.

\subsection{In vitro extracellular recordings}

Field excitatory postsynaptic potentials (fEPSPs) were recorded as described previously (Clarke and Collingridge, 2002; More et al., 2004). Responses in areas CA1 and CA3 of the hippocampus were elicited by stimulating in the Schaffer collateralcommissural fibres (CA1) or in stratum granulosum (CA3) and recording in stratum radiatum (CA1) or stratum lucidum (CA3). Data were filtered at $3-10 \mathrm{kHz}$ using an Axoclamp 2B Amplifier (Molecular Devices, Sunnyvale, CA, USA), and collected for online analysis at a sampling rate of $20 \mathrm{kHz}$ using LTP software (Anderson and Collingridge, 2007; www.winltp.com). For CA3 recordings, the presence of synaptic facilitation was established at the start of the experiment to confirm that responses were mossy fibre in origin (Lauri et al., 2001a), the amplitude was used as a measure of synaptic efficacy and stimulation intensity was adjusted so that basal fEPSP amplitude was $20-40 \%$ of maximum. For CA1 recordings, the slope of the initial rising phase of the fEPSP was used as a measure of synaptic efficacy and the stimulus intensity was set to give a basal response with slope measurement around $40 \%$ of that at which a population spike was first observed. All data are normalised to the baseline preceding any drug application.

\subsection{Sharp microelectrode intracellular recordings}

Sharp microelectrode intracellular recordings were made from CA1 pyramidal neurons as described previously (Clarke and Collingridge, 2004). Briefly, recordings were made in the discontinuous current clamp configuration (switching frequency $5-7 \mathrm{kHz}$ ) from CA1 pyramidal neurons using $2 \mathrm{M}$ potassium methylsulphate-filled electrodes (resistance 40-80 M 2 ). Monosynaptic IPSPs were obtained every $30 \mathrm{~s}$ by stimulation in the stratum radiatum close $(<0.5 \mathrm{~mm})$ to the recording site in the presence of D-AP5 $(50 \mu \mathrm{M})$ and GYKI $53655(50 \mu \mathrm{M})$. Input resistance was monitored by passing square hyperpolarising steps (amplitude 0.2-0.3 $\mathrm{nA}$; duration $500 \mathrm{~ms}$ ) through the recording electrode. Any drug-induced changes in membrane potential were adjusted, once equilibrium of effects had occurred (usually within $10 \mathrm{~min}$ of drug application), by injection of \pm d.c. current in order for comparisons of evoked IPSPs and input resistance to be made at a fixed membrane potential. All data are normalised to a $10 \mathrm{~min}$ baseline period prior to any drug application.

\subsection{Two-photon microscopy and pre-synaptic calcium imaging}

Pre-synaptic calcium imaging experiments were based on methods as described previously (Scott and Rusakov, 2006). Granule cells of the dentate gyrus were patched and held in the whole-cell configuration current-clamped at $-80 \mathrm{mV}$ for more than $1 \mathrm{~h}$ before calcium imaging, to allow for dye diffusion and equilibration. Patch pipettes contained a $\mathrm{K}^{+}$-based intracellular solution (in $\mathrm{mM}$ ): $\mathrm{K}^{+}$-methanesulfonate (150), KCl (5), HEPES (10), MgATP (3), NaGTP (0.4), pH 7.2, 285 mOsm, together with the high affinity calcium indicator Fluo- $4\left(200 \mu \mathrm{M} ; K_{\mathrm{d}} \sim 350 \mathrm{nM}\right)$ and a red morphological marker ( $20 \mu \mathrm{M}$ Alexa Fluor 594). Experiments were performed at room temperature $\left(23-26^{\circ} \mathrm{C}\right.$ ) in perfusion solution (in $\mathrm{mM}$ ): $\mathrm{NaCl}(124), \mathrm{KCl}(3)$, $\mathrm{NaHCO}_{3}(26), \mathrm{NaH}_{2} \mathrm{PO}_{4}$ (1.4), $\mathrm{CaCl}_{2}$ (2), $\mathrm{MgSO}_{4}$ (1), D-glucose (10), saturated with $95 \%$ $\mathrm{O}_{2}$ and $5 \% \mathrm{CO}_{2}$, routinely containing picrotoxin $(100 \mu \mathrm{M})$, CGP $55845(5 \mu \mathrm{M})$ and L-689,560 $(5 \mu \mathrm{M})$ to block $\mathrm{GABA}_{\mathrm{A}}, \mathrm{GABA}_{\mathrm{B}}$ and NMDA receptors, respectively.

Fast fluorescence imaging and single-cell electrophysiology were performed simultaneously using a Radiance 2100 multi-photon imaging installation (Zeiss, Oberkochen, Germany) optically linked to a Mai Tai femtosecond pulsed laser (Spectra Physics, Mountain View, CA, USA), integrated with a standard infrared DIC patch-clamp setup. Electrophysiological data were filtered at $5 \mathrm{kHz}$ using an Axopatch 200B Amplifier (Molecular Devices, Sunnyvale, CA, USA), digitised using a CED
1401 board and collected for online analysis at a sampling rate of $10 \mathrm{kHz}$ using SIGNAL version 215 (Cambridge Electronic Design Ltd, UK). Fluophores were excited at $810 \mathrm{~nm}$, with laser power adjusted for optimal emission detection from different tissue depths, and image acquisition was controlled using Laser Sharp 2000 (Zeiss). A 550LP dichroic mirror was used to separate red and green fluorescence and appropriate emission filters were placed in the green (525/50) and red (605/90) epifluorescence emission pathways. Images of slices were acquired using the 2-photon microscope in transmission mode.

Mossy fibres were traced to the CA3 area of the hippocampus by performing contiguous low resolution $(256 \times 256$ pixels; to minimise phototoxic damage $)$ Z-stacks in the red emission channel. Giant mossy fibre boutons were identified by their characteristic size (3-8 $\mu \mathrm{m}$ ) and their thin filopodial extensions (Acsady et al., 1998). Axon trajectories were fully reconstructed after each experiment (collage of kalman filtered Z-stacks), the average distance between soma and recorded bouton was $524 \pm 64 \mu \mathrm{m}(n=9)$.

Line scan images were recorded only when baseline fluorescence was stable in both the red (Alexa Fluor 594) and green (Fluo-4) emission channels. Pre-synaptic calcium signals were generated by evoking trains of orthodromic action potentials (five $2 \mathrm{~ms}$ somatic command voltage pulses at 20 or $25 \mathrm{~Hz}$ delivered via the patch pipette), recorded in fast line-scanning mode at $500 \mathrm{~Hz}$ (sweeps of up to $6 \mathrm{~s}$; $30 \mathrm{~s}-1$ min inter-sweep intervals) and stored for offline analysis. Analysis of line scan images was carried out using Laser Sharp 2000. Plot profiles of individual line scan images were collected over the area occupied by the bouton and the mean pixel density value for each time point quantified. The red morphological marker (Alexa Fluor 594) was included to relate $\mathrm{Ca}^{2+}$-dependent fluorescence (measured using Fluo-4) to $\mathrm{Ca}^{2+}$ independent fluorescence, to provide values that are independent of absolute dye concentration and insensitive to movement artifacts (Oertner et al., 2002). The profile for each line scan recorded in the "green channel" was therefore divided by its corresponding profile recorded in the "red channel" to give a fluorescence value $(\Delta F=\Delta G / R) . \Delta F / F$ values were calculated by dividing each $\Delta G / R$ profile by its own baseline $(1 \mathrm{~s})$, thus normalising to basal calcium. The boutons from which $\mathrm{Ca}^{2+}$ signals were recorded were distal from the loading site (soma) so contaminating background fluorescence (average brightness outside fluorescently labelled structures) was minimal (corresponding to PMT dark current) and was therefore not subtracted.

\subsection{Data analysis}

All pooled data are expressed as mean \pm s.e.m. Statistical significance was tested using paired Student's $t$-test or ANOVA with post hoc Bonferroni test as appropriate, with $p<0.05$ being considered significant.

\section{Results}

\subsection{Effects of ACET on human-recombinant kainate receptors expressed in HEK293 cells}

In an investigation of a series of willardiine derivatives we identified ACET as a highly potent GluK1 antagonist (Dolman et al., 2007). Here we have extended the characterisation of this compound. Fig. 1A, B illustrates concentration-response curves for the antagonism of L-glutamate-induced responses, obtained using $\mathrm{Ca}^{2+}$ fluorescent assays. None of the compounds tested had any effect on $\mathrm{Ca}^{2+}$ influx per se. ACET was highly potent as an antagonist at receptors comprising homomeric GluK1, with a $K_{\mathrm{b}}$ of $1.4 \pm 0.2 \mathrm{nM}(n=18)$ compared to the established GluK1 receptor antagonists UBP304 $\left(K_{\mathrm{b}} 110 \pm 30 \mathrm{nM} ; n=10\right), \quad$ LY382884 $\left(K_{\mathrm{b}}\right.$ $2.2 \pm 0.4 \mu \mathrm{M} ; n=14)$, and NBQX $\left(K_{\mathrm{b}} 6.2 \pm 0.6 \mu \mathrm{M} ; n=18\right)$. ACET was selective for GluK1 over GluK2, having no significant effect at concentrations up to $100 \mu \mathrm{M}$. Similar results were obtained for the GluK1 selective antagonists UBP304 and LY382884. As expected, NBQX showed no selectivity between these receptor subtypes with a similar $K_{\mathrm{b}}$ at GluK2 $(5.1 \pm 0.5 \mu \mathrm{M} ; n=27)$ to that obtained at GluK1.

To investigate effects of ACET on human GluK3 whole-cell voltage clamp recordings $\left(V_{\mathrm{h}}=-80 \mathrm{mV}\right)$ were made from single HEK293 cells, transiently transfected with human GluK3(Q). Steady-state currents evoked by $10 \mathrm{~s}$ application of $1 \mathrm{mM}$ glutamate (following pre-incubation with $500 \mu \mathrm{g} / \mathrm{ml}$ concanavalin A) were unaffected by $1 \mu \mathrm{M}$ ACET $(n=3 ; 0.3 \pm 0.3 \%)$. When the ACET concentration was increased to $30 \mu \mathrm{M}$ there was a small inhibition ( $n=7 ; 30 \pm 5 \%$ ) comparable to that observed with $30 \mu \mathrm{M}$ NBQX $(n=4 ; 29 \pm 4 \%$; Fig. $1 C)$. 


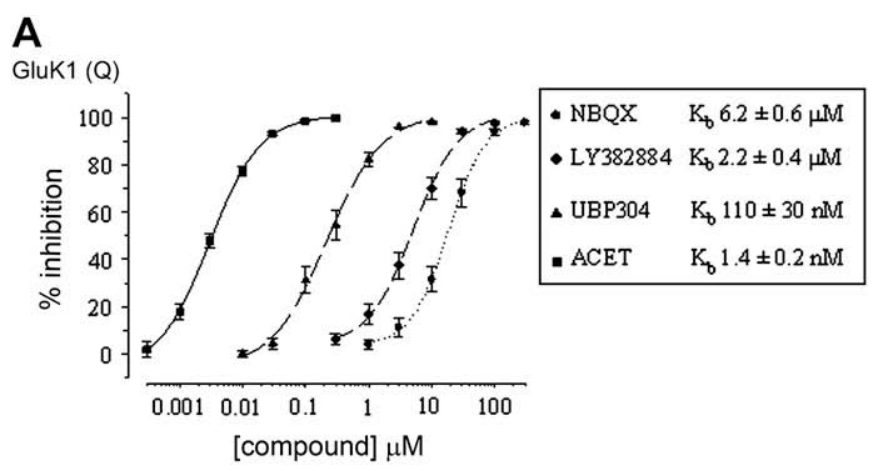

B

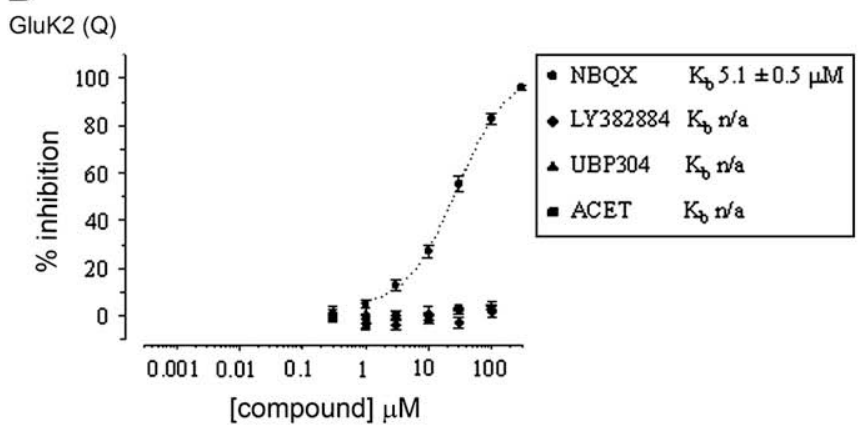

C

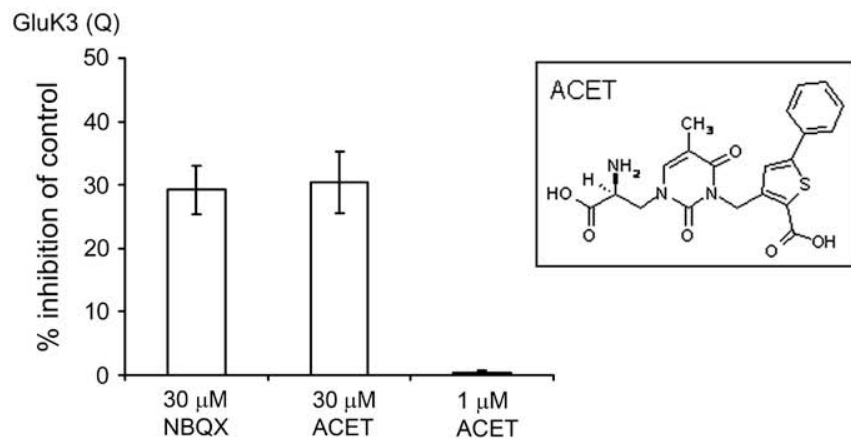

Fig. 1. ACET is a potent antagonist of GluK1 but not GluK2 or GluK3. (A, B) Doseresponse curves for antagonists in HEK293 cells transfected with human GluK1(Q) and GluK2(Q). Antagonists were tested against $30 \mu \mathrm{M}(\mathrm{A})$ and $10 \mu \mathrm{M}$ (B) glutamate, the approximate $\mathrm{EC}_{50}$ measured at the receptor subtypes, respectively. Dissociation constants $\left(K_{\mathrm{b}}\right)$ for each test compound were calculated within each individual experiment from the $\mathrm{IC}_{50}$ for inhibiting the test dose of L-glutamate using the Cheng-Prusoff equation as described in Section 2. (C) Pooled data, obtained from whole-cell patchclamp recordings of HEK293 cells transfected with human GluK3(Q), showing \% inhibition of currents evoked by $1 \mathrm{mM}$ glutamate by $30 \mu \mathrm{M} \mathrm{NBQX}(n=4 ; 29 \pm 4 \%)$, $30 \mu \mathrm{M}$ ACET $(n=7 ; 30 \pm 5 \%)$ and $1 \mu \mathrm{M}$ ACET $(n=3 ; 0.3 \pm 0.3 \%)$. Structure of ACET shown in box inset.

\subsection{X-ray crystal structure of GluK1 ACET complex}

The GluK1 ACET complex crystallized in the same space group as UBP310 contained two molecules in the asymmetric unit with a GluK1 conformation almost identical to that of UBP310. The structure was solved using data measured to Bragg spacings of $1.76 \AA$ A (Table 1). Electron density for the uracil and thiophene rings was stronger than that for the phenyl ring (Fig. 2A). Similar to the structure of other GluK1 antagonists the binding site for ACET reveals numerous protein ligand and solvent mediated contacts with both domain 1 and domain 2 (Fig. 2B). The mechanism of binding of ACET replicates that of UBP310, but with the following differences. The phenyl group of ACET forms additional van der
Waals contacts with the side chain of Asn705, and also shields parts of the main chain and side chains of residues Lys704 to Ser706 from exposure to bulk solvent, burying an extra $40 \AA^{2}$ of the protein compared to the UBP310 complex. Because the phenyl group of ACET bumps up against this region of the protein, the phenyl group is twisted by $14.5^{\circ}$ from its low energy conformation with respect to the thiophene ring in the parent compound. The phenyl ring of ACET projects into the extracellular solution, and displaces 4 ordered water molecules found in the UBP310 complex that form a hydrogen bonded network in the mouth of the binding site. The temperature factor of the ACET ligand increases progressively from its $\mathrm{N}$ to $\mathrm{C}$-terminus, and can be roughly broken down into 4 groups (Fig. 2C). The most well ordered parts of the ligand are the $\alpha$-carbon carboxylate and amino groups which bind to domain 1, followed by the uracil ring, the thiophene ring, and the phenyl ring, each of which behave as isothermal bodies. The increase in B-factor for the phenyl ring compared to the rest of the ACET molecule suggests that its interaction with the binding site of GluK1 is relatively weak compared to the thiophene and uracil rings in the parent compound. This is not surprising, since most of the phenyl ring is not in contact with protein, and if the phenyl ring was instead buried in the GluK1 binding site, a much larger increase in affinity would have occurred than measured experimentally. Thus the structural data suggest that ACET is a derivative of UBP310 in which the major role of the phenyl group is to produce an increase in lipid solubility and bioavailability, without perturbing interactions made by the functional core of the molecule.

\subsection{ACET antagonises effects mediated by GluK1-containing receptors in the CA1 of rat hippocampus}

We evaluated the effectiveness of ACET as an antagonist of native GluK1-containing KARs by testing its ability to block the actions of ATPA, a GluK1 agonist, in the CA1 region of the hippocampus (Fig. 3). ATPA depresses fEPSPs via activation of GluK1 receptors located on pre-synaptic terminals of Schaffer collateralcommissural fibres (Vignes et al., 1998). We did not include GABA antagonists in these experiments since we have shown previously that these do not affect the actions of ATPA at CA1 synapses (Clarke and Collingridge, 2002). In P14 rats, 10 and $200 \mathrm{nM}$ ACET antagonised the effects of $1 \mu \mathrm{M}$ ATPA by $37 \pm 17 \%(n=4)$ and $96 \pm 4 \%(n=4 ; p<0.05)$, respectively. ACET had no effect on low frequency evoked excitatory transmission per se suggesting that ACET has no effect on native AMPA receptors (AMPARs) at these concentrations. Next, we assessed the effect of ACET on ATPAmediated depressions of evoked GABAergic transmission in adult rats in the presence of GYKI $53655(50 \mu \mathrm{M})$ and D-AP5 $(50 \mu \mathrm{M})$ to block AMPA and NMDA receptor-mediated components of fast excitatory synaptic transmission, respectively (Fig. 4). This depression arises from the activation of GluK1 receptors on inhibitory interneurons (Clarke et al., 1997; Clarke and Collingridge, 2004). ACET ( $200 \mathrm{nM}$ ) had no effect on IPSPs per se but blocked the ATPA-evoked depression of the evoked IPSPs by $98 \pm 5 \%(n=4$; $p<0.05$ )

\subsection{ACET blocks induction of NMDA receptor-independent LTP}

We next tested the ability of ACET to block NMDAR-independent mossy fibre LTP in adult rats (Fig. 5). In the presence of 50 nM ACET (and $50 \mu \mathrm{M}$ D-AP5), high frequency stimulation (100 pulses at $100 \mathrm{~Hz}$, test intensity) consistently failed to induce LTP; fEPSP amplitude was $103 \pm 4 \%$ of control $(n=6 ; 60$ min post-induction; $p>0.05$; Fig. 5). Following a $60 \mathrm{~min}$ washout of ACET, the same induction protocol induced LTP of mossy fibre responses; fEPSP amplitude $141 \pm 7 \%$ of control $(n=6 ; 60 \mathrm{~min}$ post-induction; $p<0.005$ ). 
A

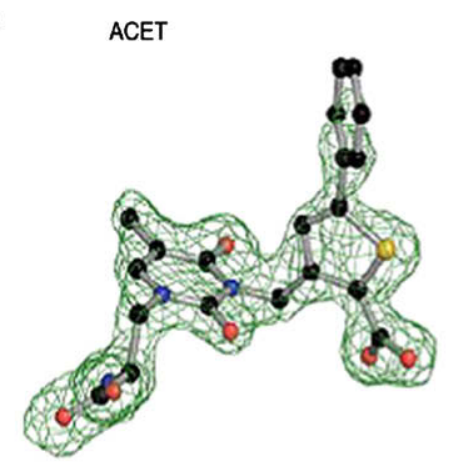

B

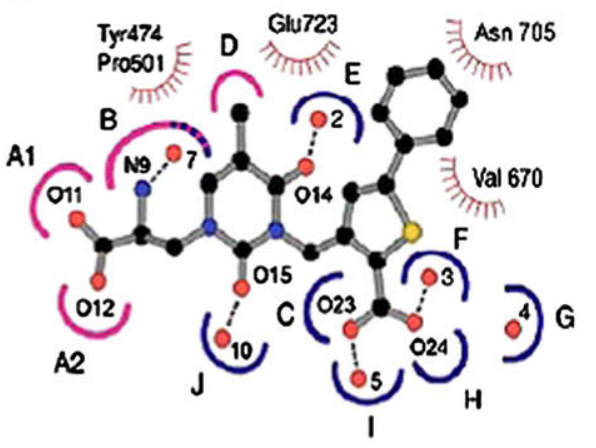

C

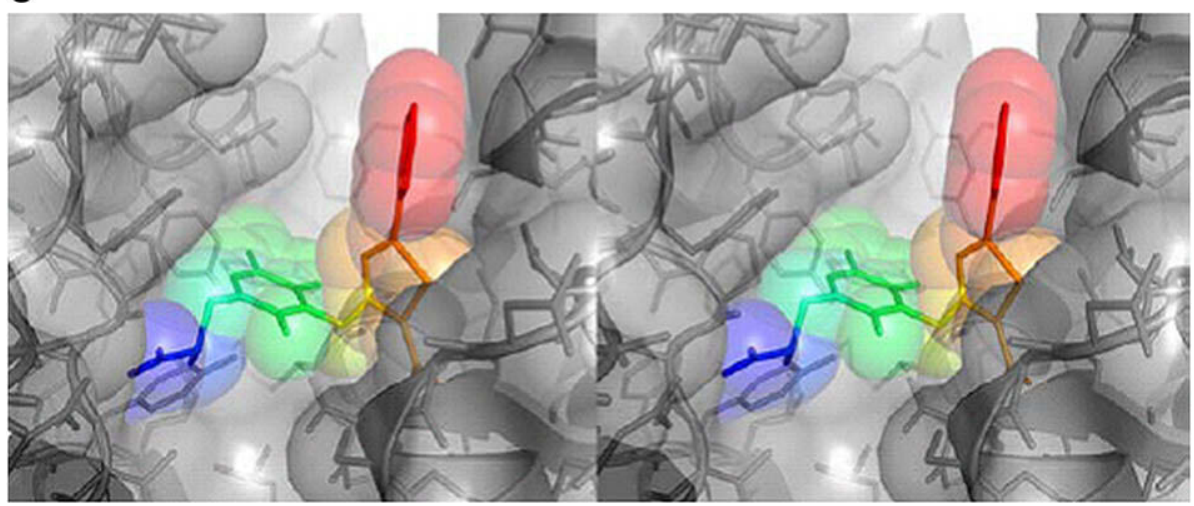

Fig. 2. Crystal structure of the GluK1 ACET complex. (A) $F_{\mathrm{o}}-F_{\mathrm{c}}$ electron density map for ACET at 1.76 Å resolution contoured at $3.5 \sigma$, with ACET omitted from the $F_{\mathrm{c}}$ calculation. (B) Subsite map for the GluK1 ligand binding pocket occupied by ACET, with amino acids from domains 1 and 2 coloured pink and blue respectively; stripes indicated sites generated by atoms from both domains. Sites B, E-G, I and J contain water molecules which connect ACET to its binding site by solvent mediated hydrogen bonds. (C) Stereoview of the ACET binding site drawn as a molecular surface; the ACET molecule is shown in CPK representation coloured by B-factor with a range of 27 (blue) to 42 (red).

\subsection{ACET inhibits short-term facilitation of pre-synaptic calcium transients}

To directly investigate the role of pre-synaptic GluK1-containing KARs we used a method for 2-photon calcium imaging of individual giant mossy fibre boutons (Scott and Rusakov, 2006). Single axons of granule cells, held in the whole-cell patch-clamp configuration, were traced into the CA3 region of the hippocampus using the red emission channel (see Section 2 for details). Orthodromic action potentials were evoked using $2 \mathrm{~ms}$ command voltage pulses to generate trains of five spikes at $20-25 \mathrm{~Hz}$ (Figs. 6A and 7B), a firing pattern compatible with granule cells in vivo (Henze et al., 2002). Action potentials were rapidly followed by fluorescence transients in giant mossy fibre boutons (Figs. 6C, D and 7C, D), which were stable for up to $2.5 \mathrm{~h}$ after breaking into the cell. Fig. $6 \mathrm{E}$ illustrates the $\mathrm{Ca}^{2+}$ responses obtained at approximately $80 \mathrm{~min}(\mathrm{t} 1)$ and $95 \mathrm{~min}(\mathrm{t} 2)$ after obtaining a whole-cell recording. In these experiments, the peak $\Delta F / F$ for control at $t 2$ was $101 \pm 6 \%$ of that recorded at 1 . Reconstructed axon trajectories were superimposed on a transmission image of the slice to illustrate where in the CA3 region the imaged bouton was located (Figs. 6B and 7B). Short-term facilitation of pre-synaptic calcium transients was consistently reduced following application of $200 \mathrm{nM}$ ACET (Fig. 7C-E: Peak $\Delta F / F$ in the presence of ACET was $54 \pm 5 \%$ of control; $n=5$; measurements time-matched with the interleaved controls). Preliminary analysis of the five $\mathrm{Ca}^{2+}$ responses evoked by each action potential revealed a dramatic effect on the last response with either only a small effect or no effect on the initial response. These data, which are consistent with recent findings of D. Rusakov (personal communication) using a different GluK1 selective antagonist (UBP302), provide direct evidence for the presence of functional pre-synaptic GluK1-containing KARs on giant mossy fibre boutons.

\section{Discussion}

In the present study we have shown that ACET is a highly potent GluK1-containing KAR antagonist with a $K_{\mathrm{b}}$ value of approximately $1 \mathrm{nM}$. In the CA3 region of the hippocampus, ACET fully blocked the induction of mossy fibre LTP in a reversible manner. ACET also consistently reduced short-term facilitation of pre-synaptic calcium transients in mossy fibre giant boutons induced by a train of action potentials. These data provide the most direct evidence to date that pre-synaptic GluK1-containing KARs play an important functional role in the regulation of synaptic facilitation and the induction of mossy fibre LTP.

\subsection{ACET as a kainate receptor antagonist}

ACET has previously been shown to be a highly potent antagonist of GluK1-containing KARs ( $K_{\mathrm{b}}$ values of $7 \pm 1$ and $5 \pm 1 \mathrm{nM}$ for recombinant GluK1 and GluK1/GluK5 receptors, respectively), but not of GluK2 or GluK2/GluK5 receptors (Dolman et al., 2007). ACET showed only a modest 1.4 -fold improvement in potency on GluK1 compared to UBP310 but was a weaker antagonist of native AMPARs, showing that ACET had improved selectivity compared to UBP310 (Dolman et al., 2007). In addition, ACET is likely to have improved bioavailability due to the increased lipophilicity provided by the phenyl ring. In this study we confirmed the selectivity and potency of ACET, using HEK293 cells expressing 


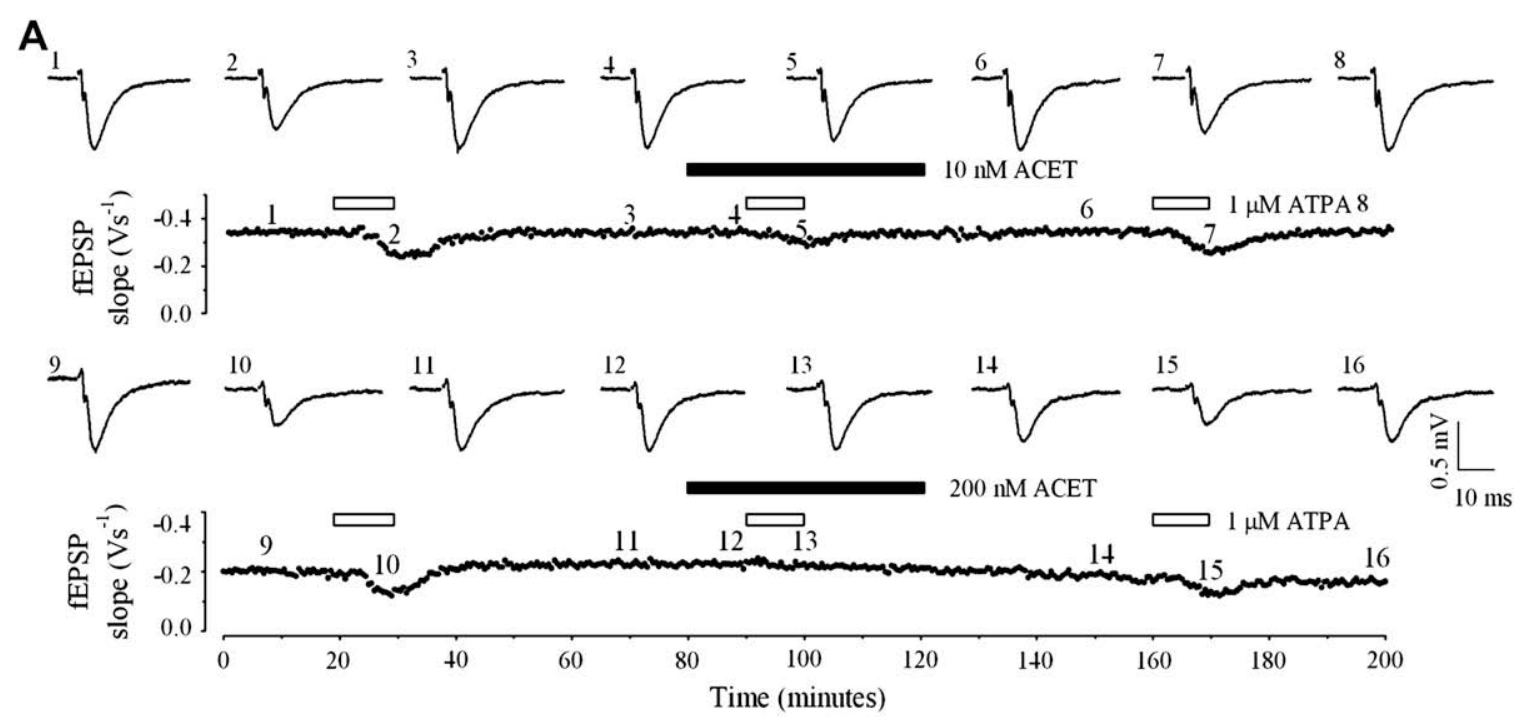

B
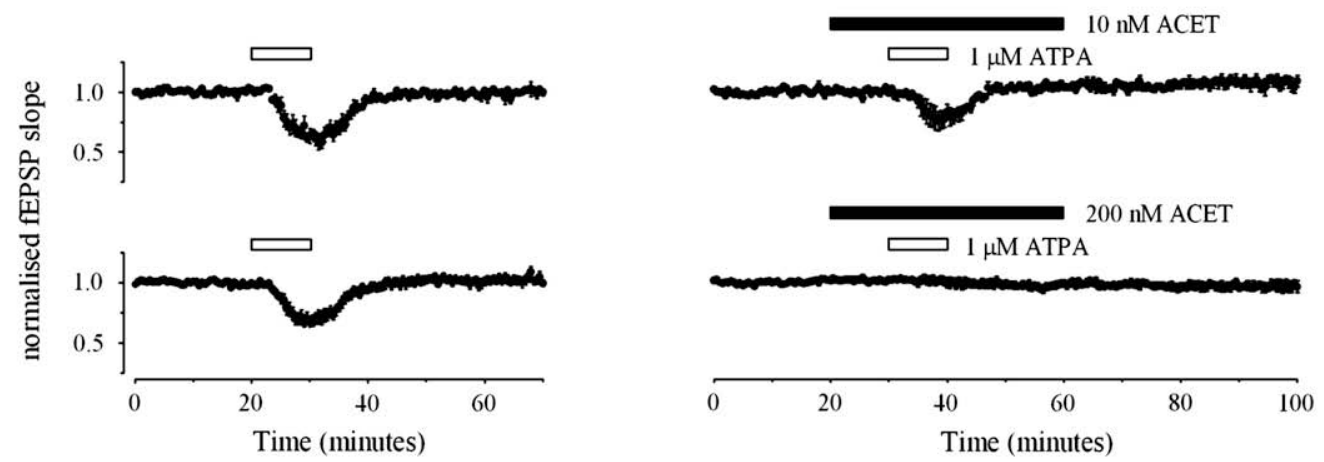

Fig. 3. ACET effectively antagonises GluK1-mediated depression of excitatory transmission in CA1 region of the hippocampus in vitro. Open bars indicate addition of the GluK1containing receptor agonist ATPA and closed bars indicate application of ACET. (A) Single representative example with traces taken at the time points illustrated for the effect of ACET on ATPA-induced depressions of evoked fEPSPs and (B) pooled data $(n=4)$.

unedited $(\mathrm{Q})$ recombinant human KAR subtypes. The rank order of potency for the tested antagonists at GluK1 was ACE$\mathrm{T} \gg \mathrm{UBP} 304>\mathrm{LY} 382884 \geq \mathrm{NBQX}$. We have shown that ACET has only low affinity for homomeric human GluK3 in a functional assay, which is in agreement with the low affinity previously reported for UBP296 (Dolman et al., 2005) and UBP304 (Dolman et al., 2006) in a competition binding assay on human GluK3. In summary, pharmacological data for ACET on a range of homomeric and

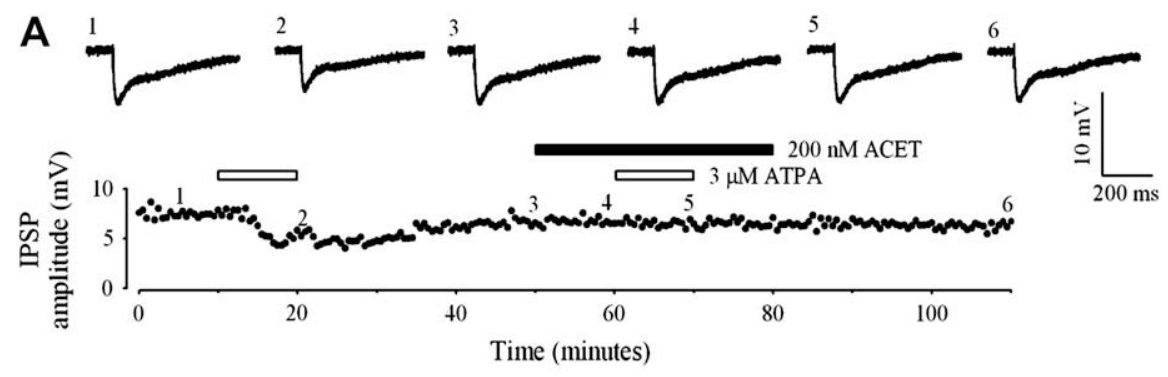

B

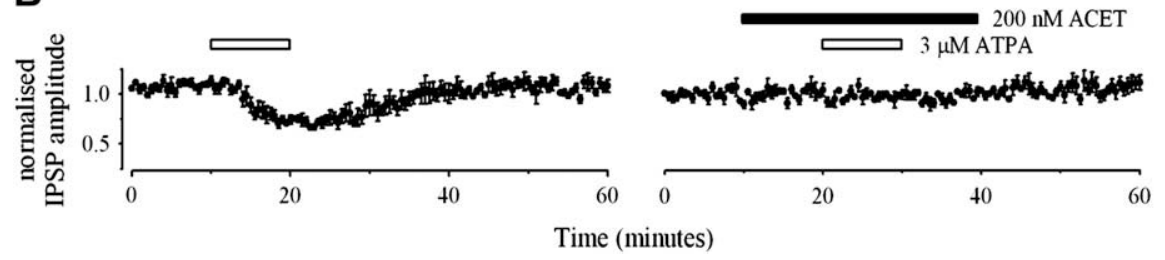

Fig. 4. ACET effectively antagonises GluK1-mediated depression of inhibitory transmission in CA1 region of the hippocampus in vitro. (A) Single example and (B) pooled data $(n=4)$ for experiments performed on monosynaptically evoked GABAergic transmission recorded in the presence of $50 \mu \mathrm{M}$ D-AP5 and $50 \mu \mathrm{M}$ GYKI 53655 . 

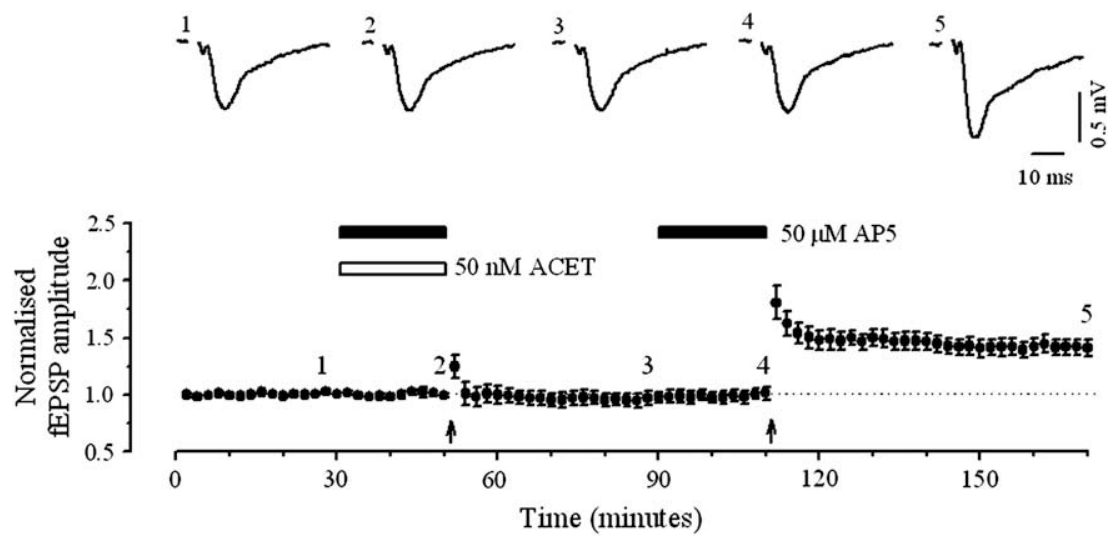

Fig. 5. ACET blocks the induction of mossy fibre LTP. Pooled data showing the effects of ACET on the induction of NMDA receptor-independent LTP in region CA3 of hippocampus. Each data point is the mean \pm s.e.m. from 6 experiments and plots the average amplitude of four successive response evoked at $0.033 \mathrm{~Hz}$ versus time. Examples of the signal averaged traces from one experiment are shown above the figure for the time points indicated (1-5). Two tetani (100 Hz, $1 \mathrm{~s}$, test intensity; indicated by arrows) were delivered in the presence of D-AP5 $(50 \mu \mathrm{M})$, the first in the presence of ACET $(50 \mathrm{nM})$ and the second following washout of ACET.

A
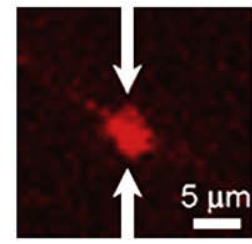

$5 \mu \mathrm{m}$

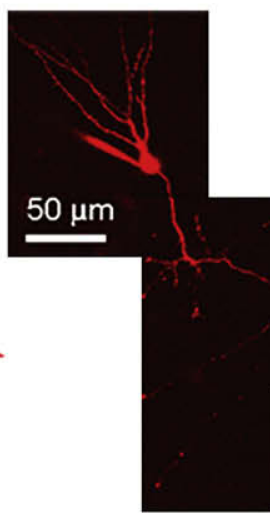

B
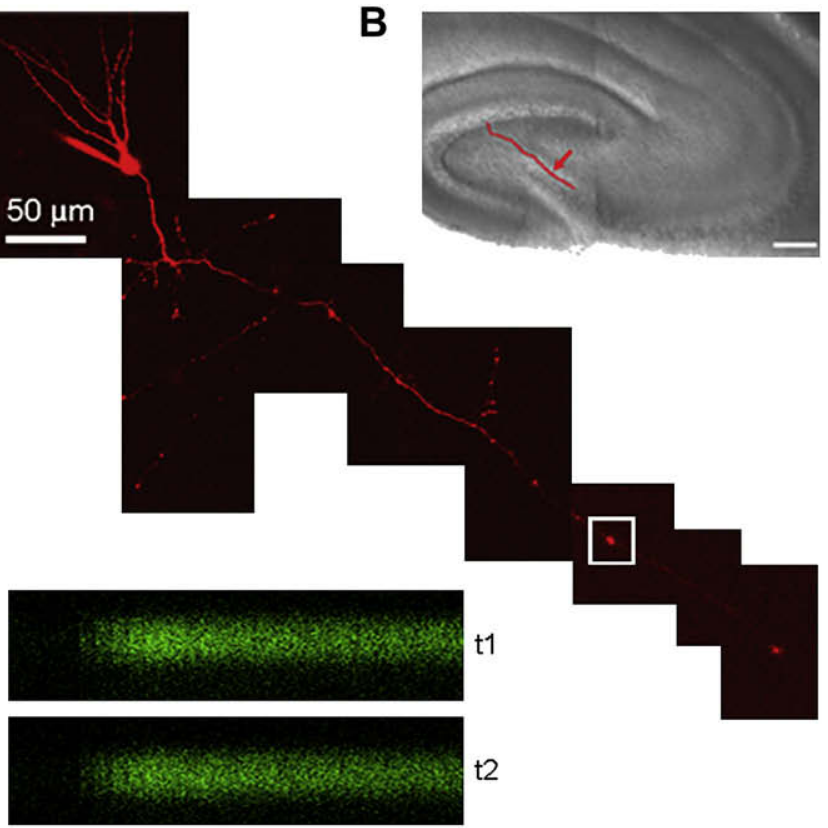

t2

IIIII $\quad \overline{200 \mathrm{se}}$
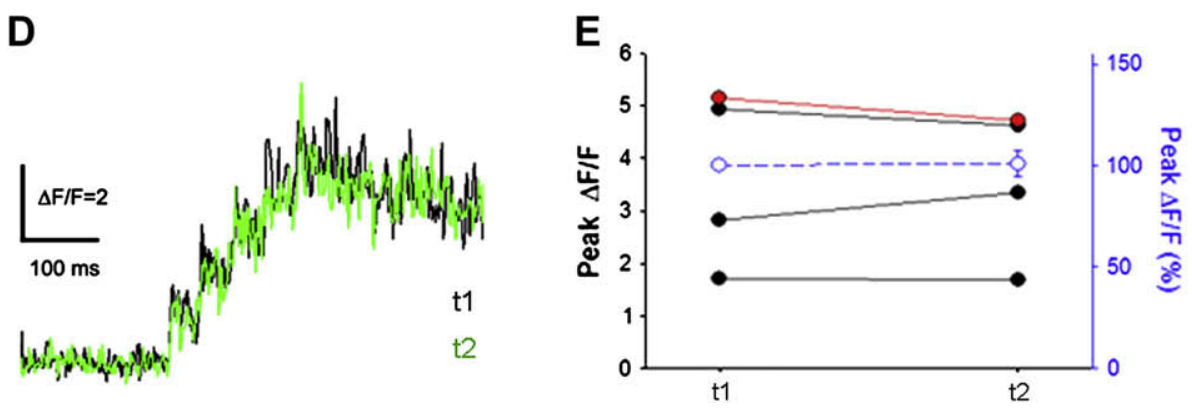

Fig. 6. Stability of pre-synaptic calcium transients recorded at individual giant mossy fibre boutons using 2-photon excitation microscopy. (A) Granule cell (patch-loaded with Alexa Fluor 594 and Fluo-4) with axon traced into CA3 region using the red emission channel, and action potentials recorded following injection of current via the patch pipette (5 at $25 \mathrm{~Hz}$ ). (B) Axon trajectory for cell shown in A, created by superimposing the reconstructed axon on the transmission image of slice. The thick red line is a freehand trace of the axon (to aid visualisation) and the red arrow indicates location of giant bouton indicated by white square in A. Scale bar $=200 \mu \mathrm{m}$. (C) Line scan (position indicated by white arrows) fluorescence transients recorded from giant mossy fibre bouton (same bouton as indicated by white square in A and red arrow in B). Fluorescence transients are averages of 5 successive scans under control conditions at 2 different time points: $\mathrm{t} 1$ (approximately $80 \mathrm{~min}$ after obtaining a whole-cell recording) corresponds to the control time point in Fig. 7C-E, and $\mathrm{t} 2$ ( $15 \mathrm{~min}$ later) corresponds to the time point where recordings were made in the presence of ACET (Fig. 7C-E). Action potentials are indicated by vertical black bars. (D) Profiles of fluorescence transients shown in C (each trace is an average of 5 successive scans). (E) Peak fluorescence for individual cells (representative cell shown in red) and pooled data showing percentage change (blue, $n=4$ ). 

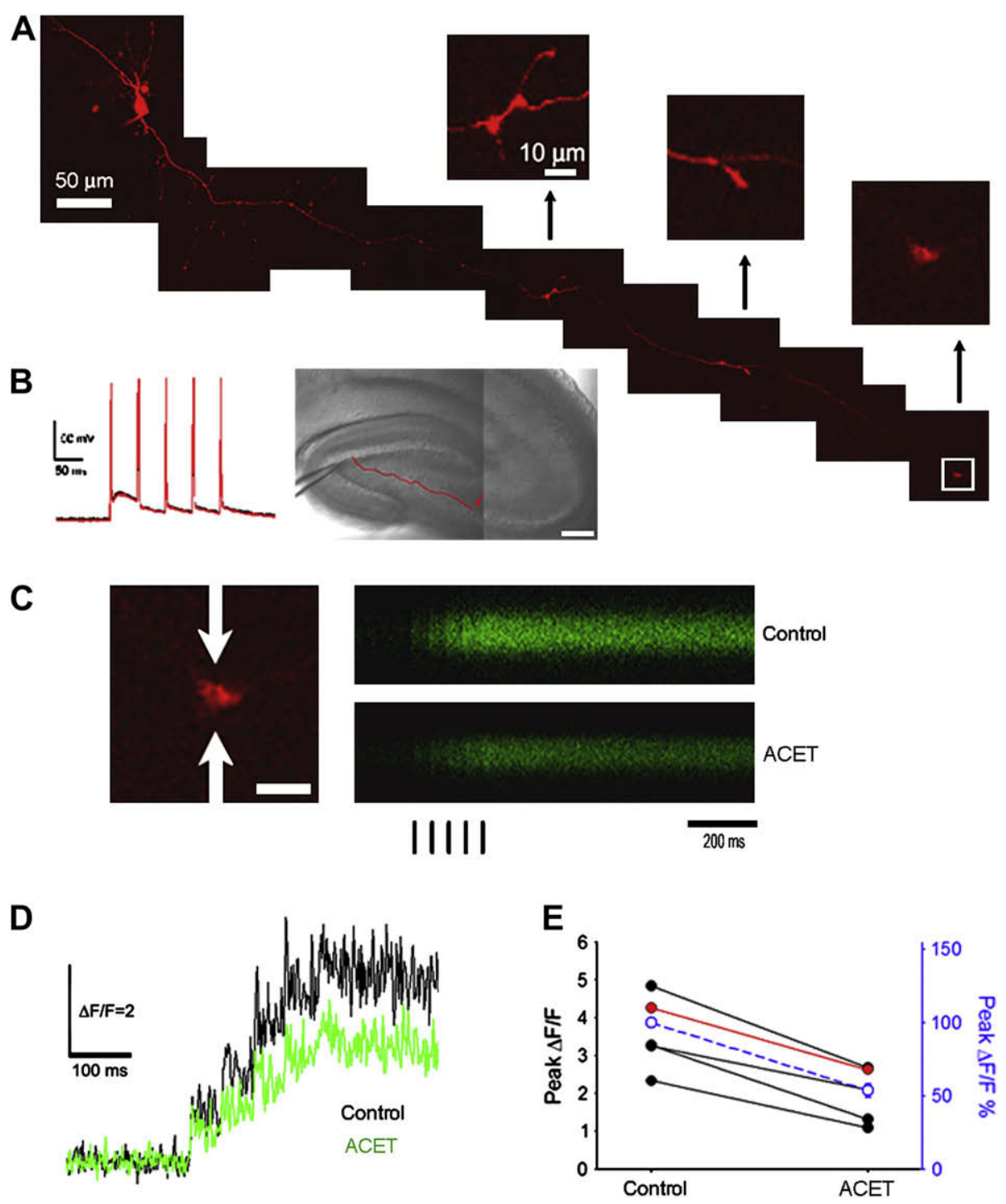

Fig. 7. ACET ( $200 \mathrm{nM})$ reduces short-term facilitation of pre-synaptic calcium transients following repetitive spikes. (A) Axon of granule cell traced into CA3 region and three giant boutons. (B) Action potentials ( 5 at $20 \mathrm{~Hz}$ ) recorded before (black) and after (red) application of ACET and axon trajectory for cell shown in A (red arrow indicates location of giant bouton indicated by white square in A). Scale bar $=200 \mu \mathrm{m}$. (C) Fluorescence transients (averages of 5 successive scans) recorded from giant mossy fibre bouton shown (same as indicated by white square in A and red arrow in B; white arrows indicate position of line scan; scale bar $=10 \mu \mathrm{m}$ ) before and after application of ACET. Action potentials are indicated by vertical black bars. (D) Profiles of fluorescence transients shown in C (each trace is an average of 5 successive scans) before (black) and in the presence of $200 \mathrm{nM}$ ACET (green). (E) Peak fluorescence for individual cells (representative cell shown in red) and pooled data showing percentage change (blue, $n=5$ ).

heteromeric kainate receptor subtypes suggest that ACET is selective for homomeric GluK1 and heteromeric GluK1-containing kainate receptors. However, ACET has not been tested on all possible combinations of KAR subunits so it remains a possibility that it may have antagonist effects on some heteromeric combinations of KAR subunits that do not include the GluK1 subunit. In addition, it is possible that the selectivity of ACET would be different depending on the species of recombinant receptor used or the methods used to evaluate its activity (e.g., speed of agonist application, presence of allosteric modulator).

We then went on to show that ACET is an effective antagonist of native GluK1-containing KARs in vitro at nanomolar concentrations: $200 \mathrm{nM}$ ACET completely blocked ATPA-mediated depressions of both evoked fEPSPs (Vignes et al., 1998; Clarke and Collingridge, 2002) and IPSPs (Clarke et al., 1997; Clarke and Collingridge, 2004) in area CA1 of the hippocampus. At these concentrations, ACET had no effect on AMPAR-mediated synaptic transmission or $G_{A B A} R$ - or $\mathrm{GABA}_{B} \mathrm{R}$-mediated synaptic transmission. Previously, we reported that ACET $(1 \mu \mathrm{M})$ had no effect on NMDA or DHPG-induced depolarisations of spinal neurons (Dolman et al., 2007). Thus, ACET is not only a highly potent antagonist but also shows considerable selectivity.

\subsection{X-ray crystal structure of ACET GluK1 complex}

The structure of GluK1 in the GluK1 ACET complex was similar to that reported for the GluK1 UBP310 complex (Mayer et al., 2006). The phenyl ring of ACET provided only a modest increase in affinity for GluK1 compared to UBP310, which has a similar structure to ACET but without the phenyl ring at the 2-position of the thiophene ring. Additional van der Waals contacts with Val670 and the side chain of Asn705 are the likely reason for the slight increase in affinity. The lower potency of ACET versus UBP310 on native AMPARs is likely due to steric interaction of the phenyl group of ACET with the bulkier Leu650 residue in AMPARs, which replaces Val670 in GluK1.

A major factor in the lack of effect of ACET on GluK2 is due to two substitutions in GluK2 that replace important residues in GluK1; 
these are Ala437 which replaces Thr503 and Ala658, which replaces Ser674. These substitutions lead to loss of a direct hydrogen bond of the $\alpha$-amino group of ACET to Thr503. This is particularly detrimental, as the $\alpha$-amino group of ACET does not form the direct ionic interaction with Glu723 in GluK1 observed in the structures of AMPAR antagonist GluA2 complexes. With respect to GluK3 (formerly GluR7) it is likely that the replacement of Ser674 with an Ala residue will lower the affinity of ACET for this subunit. There may also be a role for Asn690 in GluK2 and Asn691 in GluK3, which are replaced by a serine residue in GluK1, in limiting the interactions. These larger side chains may interfere with the correct placement of the thiophene ring bearing the terminal carboxylic acid and lower the affinity of ACET for GluK2 and GluK3. In combination, these substitutions are the likely explanation for the observed low affinity of UBP296, UBP304 and ACET for GluK3 (see also, Dolman et al., 2005, 2006). Further studies are required to determine if this asparagine residue plays a role in interfering with the binding of antagonists such as ACET to GluK2 and GluK3.

\subsection{GluK1-containing receptors and mossy fibre LTP}

The mossy fibre pathway in the hippocampus remains the best characterised KAR-mediated response in the brain (Castillo et al., 1997; Vignes and Collingridge, 1997). In addition to mediating a component of synaptic transmission, KARs mediate the induction of synaptic plasticity at this synapse (Bortolotto et al., 1999; Contractor et al., 2001; Schmitz et al., 2003). However, there is a controversy surrounding whether the KAR responsible for the induction of mossy fibre LTP contains the GluK1 subunit or not. On the one-hand, mossy fibre LTP has been shown to be blocked by LY382884 (Bortolotto et al., 1999), UBP296 (More et al., 2004) and UBP302 (Dolman et al., 2005). On the other hand, mossy fibre LTP is absent in the GluK2 knockout but not the GluK1 knockout (Contractor et al., 2001), reduced in the GluK3 knockout (Pinheiro et al., 2007), and has also been reported to be resistant to LY382884 (Breustedt and Schmitz, 2004). In the current study, ACET, the most selective GluK1 antagonist developed to date, reliably blocked the induction of mossy fibre LTP (defined by its resistance to NMDAR antagonism) at low nanomolar concentrations. Thus, whilst it cannot be totally excluded that all of the compounds (LY382884, UBP296, UBP302 and ACET) block a different native KAR to produce these effects, the simplest explanation is that GluK1-containing KARs play a key role in this form of synaptic plasticity.

Whatever the target of these GluK1 antagonists to block mossy fibre LTP there has to be an explanation why one study failed to block mossy fibre LTP with LY382884 (Breustedt and Schmitz, 2004). One possibility is that there are two (or perhaps more) forms of mossy fibre LTP and that only one of these is sensitive to the actions of the various GluK1 antagonists. It is well established that there are multiple forms of mossy fibre synaptic plasticity that differ depending on the CA3 neuronal target (Maccaferri et al., 1998; Pelkey et al., 2006). Further work will be required to establish if there is an anatomical explanation for these differing results with KAR antagonists.

\subsection{GluK1-containing receptors and synaptic facilitation}

KARs have also been shown to play an important role in synaptic facilitation at mossy fibre-CA3 synapses (Bortolotto et al., 1999, 2003; Lauri et al., 2001a; Schmitz et al., 2001). Once again, however, there is a controversy surrounding the involvement of the GluK1 subtype. Evidence for a role is again based on the effects of LY382884 (Lauri et al., 2001a, 2003) whilst evidence against is based on the lack of sensitivity of synaptic facilitation to this compound and that synaptic facilitation is preserved in GluK1 knockouts (Contractor et al., 2001; Breustedt and Schmitz, 2004) but impaired in GluK2 (Contractor et al., 2001; Breustedt and Schmitz, 2004) and GluK3 knockouts (Pinheiro et al., 2007). There is a direct correlation between the sensitivity to GluK1 antagonists of synaptic facilitation and mossy fibre LTP. Thus, whatever the explanation for one is likely to be the explanation of the other.

Previously we reported that the effects of LY382884 on synaptic facilitation were mimicked by compounds that impaired $\mathrm{Ca}^{2+}$ release from intracellular stores and suggested therefore that activation of GluK1-containing receptors triggered $\mathrm{Ca}^{2+}$-induced $\mathrm{Ca}^{2+}$ release from mossy fibre boutons, possibly in response to $\mathrm{Ca}^{2+}$ permeation through unedited GluK1-containing KARs (Lauri et al., 2003). To address this more directly we set out to image $\mathrm{Ca}^{2+}$ within individual mossy fibre boutons. During the course of this work it was reported that $\mathrm{Ca}^{2+}$-induced $\mathrm{Ca}^{2+}$ release did indeed boost the $\mathrm{Ca}^{2+}$ signal evoked by high frequency action potential trains (Scott and Rusakov, 2006). Interestingly, this effect was observed only at giant mossy fibre synapses made onto CA3 pyramidal cells. At synapses onto interneurons there was no evidence for a role of $\mathrm{Ca}^{2+}$-induced $\mathrm{Ca}^{2+}$ release. Furthermore, the contribution of $\mathrm{Ca}^{2+}$ stores was eliminated by blocking KARs using NBQX, confirming an association between KARs and $\mathrm{Ca}^{2+}$ release from intracellular stores in giant mossy fibre boutons (Scott et al., 2006). We were therefore interested to know whether the $\mathrm{Ca}^{2+}$ signals recorded in giant mossy fibre boutons during repetitive stimulation are sensitive to GluK1 antagonists, as our model predicts. Evidence that this is indeed the case was first observed by D. Rusakov using UBP302 (personal communication) and confirmed here using ACET. Thus, KARs that are sensitive to these GluK1 antagonists do indeed regulate $\mathrm{Ca}^{2+}$ signalling in giant mossy fibre boutons.

\subsection{Concluding remarks}

The finding that ACET blocks the induction of both mossy fibre LTP and inhibits $\mathrm{Ca}^{2+}$ signalling in giant mossy fibre boutons during repetitive stimulation is consistent with the model (Lauri et al., 2001a, 2003) that pre-synaptic GluK1-containing KARs are important for these two synaptic processes.

\section{Acknowledgements}

Research funded by the MRC and the BBSRC. Synchrotron diffraction data were collected at Southeast Regional Collaborative Access Team (SER-CAT) 22-ID beamline at the Advanced Photon Source, Argonne National Laboratory. Use of the Advanced Photon Source was supported by the U.S. Department of Energy, Office of Science, Office of Basic Energy Sciences, under Contract No. W-31109-Eng-38. This work was supported in part by the intramural research program of NICHD, NIH, DHHS (MLM).

\section{References}

Acsady, L., Kamondi, A., Sik, A., Freund, T., Buzsaki, G., 1998. GABAergic cells are the major postsynaptic targets of mossy fibers in the rat hippocampus. Journal of Neuroscience 18, 3386-3403.

Anderson, W.W., Collingridge, G.L., 2007. Capabilities of the WinLTP data acquisition program extending beyond basic LTP experimental functions. Journal of Neuroscience Methods 162, 346-356.

Barker, G.R., Warburton, E.C., Koder, T., Dolman, N.P., More, J.C., Aggleton, J.P., Bashir, Z.I., Auberson, Y.P., Jane, D.E., Brown, M.W., 2006. The different effects on recognition memory of perirhinal kainate and NMDA glutamate receptor antagonism: implications for underlying plasticity mechanisms. Journal of Neuroscience 26, 3561-3566.

Blackburn-Munro, G., Bomholt, S.F., Erichsen, H.K., 2004. Behavioural effects of the novel AMPA/GluR5 selective receptor antagonist NS1209 after systemic administration in animal models of experimental pain. Neuropharmacology 47, 351-362

Bleakman, D., Ballyk, B.A., Schoepp, D.D., Palmer, A.J., Bath, C.P., Sharpe, E.F., Woolley, M.L., Bufton, H.R., Kamboj, R.K., Tarnawa, I., Lodge, D., 1996. Activity of 2,3-benzodiazepines at native rat and recombinant human glutamate receptors 
in vitro: stereospecificity and selectivity profiles. Neuropharmacology 35 , 1689-1702.

Bleakman, D., Alt, A., Nisenbaum, E.S., 2006. Glutamate receptors and pain. Seminars in Cell and Developmental Biology 17, 592-604.

Bleisch, T.J., Ornstein, P.L., Allen, N.K., Wright, R.A., Lodge, D., Schoepp, D.D., 1997 Structure-activity studies of aryl-spaced decahydroisoquinoline-3-carboxylic acid AMPA receptor antagonists. Bioorganic \& Medicinal Chemistry Letters 7 , $1161-1166$.

Bortolotto, Z.A., Clarke, V.R., Delany, C.M., Parry, M.C., Smolders, I., Vignes, M., Ho, K.H., Miu, P., Brinton, B.T., Fantaske, R., Ogden, A., Gates, M., Ornstein, P.L. Lodge, D., Bleakman, D., Collingridge, G.L., 1999. Kainate receptors are involved in synaptic plasticity. Nature 402, 297-301.

Bortolotto, Z.A., Lauri, S., Isaac, J.T., Collingridge, G.L., 2003. Kainate receptors and the induction of mossy fibre long-term potentiation. Philosophical Transactions of the Royal Society 358, 657-666.

Breustedt, J., Schmitz, D., 2004. Assessing the role of GLUK5 and GLUK6 at hippocampal mossy fiber synapses. Journal of Neuroscience 24, 10093-10098.

Castillo, P.E., Malenka, R.C., Nicoll, R.A., 1997. Kainate receptors mediate a slow postsynaptic current in hippocampal CA3 neurons. Nature 388, 182-186.

Clarke, V.R., Ballyk, B.A., Hoo, K.H., Mandelzys, A., Pellizzari, A., Bath, C.P., Thomas, J., Sharpe, E.F., Davies, C.H., Ornstein, P.L., Schoepp, D.D., Kamboj, R.K., Collingridge, G.L., Lodge, D., Bleakman, D., 1997. A hippocampal GluR5 kainate receptor regulating inhibitory synaptic transmission. Nature 389, 599-603.

Clarke, V.R., Collingridge, G.L., 2002. Characterisation of the effects of ATPA a GLU(K5) receptor selective agonist, on excitatory synaptic transmission in area CA1 of rat hippocampal slices. Neuropharmacology 42, 889-902.

Clarke, V.R., Collingridge, G.L., 2004. Characterisation of the effects of ATPA a GLU(K5) kainate receptor agonist, on GABAergic synaptic transmission in the CA1 region of rat hippocampal slices. Neuropharmacology 47, 363-372.

Collingridge, G.L., Olsen, R.W., Peters, J., Spedding, M., 2009. A nomenclature for ligand-gated ion channels. Neuropharmacology 56, 2-5.

Contractor, A., Swanson, G., Heinemann, S.F., 2001. Kainate receptors are involved in short- and long-term plasticity at mossy fiber synapses in the hippocampus. Neuron 29, 209-216.

DeLano, W.L., 2002. The PyMOL Molecular Graphics System. DeLano Scientific, Palo Alto, CA, USA.

Dolman, N.P., Troop, H.M., More, J.C., Alt, A., Knauss, J.L., Nistico, R., Jack, S., Morley, R.M., Bortolotto, Z.A., Roberts, P.J., Bleakman, D., Collingridge, G.L. Jane, D.E., 2005. Synthesis and pharmacology of willardiine derivatives acting as antagonists of kainate receptors. Journal of Medicinal Chemistry 48, 7867-7881.

Dolman, N.P., More, J.C., Alt, A., Knauss, J.L., Troop, H.M., Bleakman, D., Collingridge, G.L., Jane, D.E., 2006. Structure-activity relationship studies on N3-substituted willardiine derivatives acting as AMPA or kainate receptor antagonists. Journal of Medicinal Chemistry 49, 2579-2592.

Dolman, N.P., More, J.C., Alt, A., Knauss, J.L., Pentikainen, O.T., Glasser, C.R., Bleakman, D., Mayer, M.L., Collingridge, G.L., Jane, D.E., 2007. Synthesis and pharmacological characterization of N3-substituted willardiine derivatives: role of the substituent at the 5-position of the uracil ring in the development of highly potent and selective GLUK5 kainate receptor antagonists. Journal of Medicinal Chemistry 50, 1558-1570.

Emsley, P., Cowtan, K., 2004. Coot: model-building tools for molecular graphics Acta Crystallographica. Section D, Biological Crystallography 60, 2126-2132.

Fisahn, A., 2005. Kainate receptors and rhythmic activity in neuronal networks: hippocampal gamma oscillations as a tool. Journal of Physiology 562, 65-72.

Henze, D.A., Wittner, L., Buzsaki, G., 2002. Single granule cells reliably discharge targets in the hippocampal CA3 network in vivo. Nature Neuroscience 5 790-795.

Huxter, J.R., Zinyuk, L.E., Roloff, E.L., Clarke, V.R., Dolman, N.P., More, J.C., Jane, D.E. Collingridge, G.L., Muller, R.U., 2007. Inhibition of kainate receptors reduces the frequency of hippocampal theta oscillations. Journal of Neuroscience 27, 22122223

Jane, D.E., Lodge, D., Collingridge, G.L., 2009. Kainate receptors: pharmacology, function and therapeutic potential. Neuropharmacology 56, 90-113.

Lauri, S.E., Bortolotto, Z.A., Bleakman, D., Ornstein, P.L., Lodge, D., Isaac, J.T., Collingridge, G.L., 2001a. A critical role of a facilitatory presynaptic kainate receptor in mossy fiber LTP. Neuron 32, 697-709.

Lauri, S.E., Delany, C., Clarke, V.R.J., Bortolotto, Z.A., Ornstein, P.L., Isaac, T.R., Collingridge, G.L., 2001b. Synaptic activation of a presynaptic kainate receptor facilitates AMPA receptor-mediated synaptic transmission at hippocampal mossy fibre synapses. Neuropharmacology 41, 907-915.

Lauri, S.E., Bortolotto, Z.A., Nistico, R., Bleakman, D., Ornstein, P.L., Lodge, D. Isaac, J.T., Collingridge, G.L., 2003. A role for $\mathrm{Ca}^{2+}$ stores in kainate receptor- dependent synaptic facilitation and LTP at mossy fiber synapses in the hippocampus. Neuron 39, 327-341.

Lerma, J., 2003. Roles and rules of kainate receptors in synaptic transmission. Nature Reviews. Neuroscience 4, 481-495.

Maccaferri, G., Toth, K., McBain, C.J., 1998. Target-specific expression of presynaptic mossy fiber plasticity. Science 279, 1368-1370.

Mayer, M.L., 2005. Crystal structures of the GluR5 and GluR6 ligand binding cores: molecular mechanisms underlying kainate receptor selectivity. Neuron 45 , 539-552.

Mayer, M.L., Ghosal, A., Dolman, N.P., Jane, D.E., 2006. Crystal structures of the kainate receptor GluR5 ligand binding core dimer with novel GluR5-selective antagonists. Journal of Neuroscience 26, 2852-2861.

More, J.C., Troop, H.M., Jane, D.E., 2002. The novel antagonist 3-CBW discriminates between kainate receptors expressed on neonatal rat motoneurones and those on dorsal root C-fibres. British Journal of Pharmacology 137, 1125-1133.

More, J.C., Troop, H.M., Dolman, N.P., Jane, D.E., 2003. Structural requirements for novel willardiine derivatives acting as AMPA and kainate receptor antagonists. British Journal of Pharmacology 138, 1093-1100.

More, J.C., Nistico, R., Dolman, N.P., Clarke, V.R., Alt, A.J., Ogden, A.M., Buelens, F.P., Troop, H.M., Kelland, E.E., Pilato, F., Bleakman, D., Bortolotto, Z.A., Collingridge, G.L., Jane, D.E., 2004. Characterisation of UBP296: a novel, potent and selective kainate receptor antagonist. Neuropharmacology 47, 46-64.

Mulle, C., Sailer, A., Perez-Otano, I., Dickinson-Anson, H., Castillo, P.E., Bureau, I. Maron, C., Gage, F.H., Mann, J.R., Bettler, B., Heinemann, S.F., 1998. Altered synaptic physiology and reduced susceptibility to kainate-induced seizures in GluR6-deficient mice. Nature 392, 601-605.

O’Neill, M.J., Bond, A., Ornstein, P.L., Ward, M.A., Hicks, C.A., Hoo, K., Bleakman, D. Lodge, D., 1998. Decahydroisoquinolines: novel competitive AMPA/kainate antagonists with neuroprotective effects in global cerebral ischaemia. Neuropharmacology 37, 1211-1222.

Oertner, T.G., Sabatini, B.L., Nimchinsky, E.A., Svoboda, K., 2002. Facilitation at single synapses probed with optical quantal analysis. Nature Neuroscience 5, 657-664.

Painter, J., Merritt, E.A., 2006. Optimal description of a protein structure in terms of multiple groups undergoing TLS motion. Acta Crystallographica. Section D, Biological Crystallography 62, 439-450.

Pelkey, K.A., Topolnik, L., Lacaille, J.C., McBain, C.J., 2006. Compartmentalized Ca(2+) channel regulation at divergent mossy-fiber release sites underlies target celldependent plasticity. Neuron 52, 497-510.

Pinheiro, P.S., Mulle, C., 2008. Presynaptic glutamate receptors: physiological functions and mechanisms of action. Nature Reviews. Neuroscience 9, 423-436.

Pinheiro, P.S., Perrais, D., Coussen, F., Barhanin, J., Bettler, B., Mann, J.R., Malva, J.O., Heinemann, S.F., Mulle, C., 2007. GluR7 is an essential subunit of presynaptic kainate autoreceptors at hippocampal mossy fiber synapses. Proceedings of the National Academy of Sciences of the United States of America 104, 12181-12186.

Schmitz, D., Mellor, J., Nicoll, R.A., 2001. Presynaptic kainate receptor mediation of frequency facilitation at hippocampal mossy fiber synapses. Science 291, 1972 1976.

Schmitz, D., Mellor, J., Breustedt, J., Nicoll, R.A., 2003. Presynaptic kainate receptors impart an associative property to hippocampal mossy fiber long-term potentiation. Nature Neuroscience 6, 1058-1063.

Scott, R., Kullmann, D.M., Rusakov, D.A., 2006. Cell target specific presynaptic actions of kainate receptors at individual mossy fibre synapses. Proceedings of the Physiological Society 3, PC168.

Scott, R., Rusakov, D.A., 2006. Main determinants of presynaptic $\mathrm{Ca}^{2+}$ dynamics at individual mossy fiber-CA3 pyramidal cell synapses. Journal of Neuroscience 26, 7071-7081.

Shaltiel, G., Maeng, S., Malkesman, O., Pearson, B., Schloesser, R.J., Tragon, T., Rogawski, M., Gasior, M., Luckenbaugh, D., Chen, G., Manji, H.K., 2008. Evidence for the involvement of the kainate receptor subunit GluR6 (GRIK2) in mediating behavioral displays related to behavioral symptoms of mania. Molecular Psychiatry 13, 858-872.

Vignes, M., Collingridge, G.L., 1997. The synaptic activation of kainate receptors. Nature 388, 179-182.

Vignes, M., Clarke, V.R., Parry, M.J., Bleakman, D., Lodge, D., Ornstein, P.L. Collingridge, G.L., 1998. The GluR5 subtype of kainate receptor regulates excitatory synaptic transmission in areas CA1 and CA3 of the rat hippocampus. Neuropharmacology 37, 1269-1277.

Vincent, P., Mulle, C. Kainate receptors in epilepsy and excitotoxicity. Neuroscience, in press.

Winn, M.D., Isupov, M.N., Murshudov, G.N., 2001. Use of TLS parameters to model anisotropic displacements in macromolecular refinement. Acta Crystallographica. Section D, Biological Crystallography 57, 122-133. 